\title{
Biallelic and de novo variants in ATP6VOA1 cause progressive myoclonus epilepsy and developmental and epileptic encephalopathy
}

Laura C Bott ${ }^{1, \dagger}$, Mitra Forouhan ${ }^{2, \dagger}$, Maria Lieto ${ }^{3,4}$, Ambre J Sala ${ }^{1}$, Ruth Ellerington ${ }^{2}$, Janel O Johnson $^{5}$, Alfina A Speciale ${ }^{2}$, Chiara Criscuolo ${ }^{4}$, Alessandro Filla ${ }^{4}$, David Chitayat ${ }^{6}$, Andrea $\mathrm{H} \mathrm{Nemeth}^{7}$, Italian Undiagnosed Diseases Network, Francesco Angelucci ${ }^{8}$, Wooi Fang Lim², Pasquale Striano ${ }^{9}$, Federico Zara ${ }^{9}$, Ingo Helbig ${ }^{10}$, Mikko Muona ${ }^{11,12}$, Carolina Courage ${ }^{12}$, Anna-Elina Lehesjoki ${ }^{12}$, Samuel F Berkovic ${ }^{13}$, V-ATPase Consortium, Kenneth $\mathrm{H}$ Fischbeck $^{14}$, Francesco Brancati ${ }^{8,15}$, Richard I Morimoto ${ }^{1}$, Matthew JA Wood ${ }^{2,16}$, Carlo Rinaldi $^{2}$

\section{Author affiliations:}

${ }^{1}$ Department of Molecular Biosciences, Rice Institute for Biomedical Research, Northwestern University, Evanston, Illinois 60208, USA.

${ }^{2}$ Department of Paediatrics, University of Oxford, Oxford OX1 3QX, UK.

${ }^{3}$ Department of Physiology, Anatomy and Genetics, Oxford OX1 3QX, UK.

${ }^{4}$ Department of Neurosciences, Reproductive and Odontostomatological Sciences Federico II University, Naples 80121, Italy.

${ }^{5}$ Neuromuscular Diseases Research Section, Laboratory of Neurogenetics, National Institute on Aging, National Institutes of Health, Bethesda, Maryland 20892, USA.

${ }^{6}$ Division of Clinical and Metabolic Genetics, Department of Pediatrics, The Hospital for Sick Children, University of Toronto, Toronto, Ontario M5G 1X8, Canada; The Prenatal Diagnosis and Medical Genetics Program, Department of Obstetrics and Gynecology, Mount Sinai Hospital, University of Toronto, Toronto, Ontario M5G 1X5, Canada.

${ }^{7}$ Nuffield Department of Clinical Neurosciences, University of Oxford, Oxford OX3 9DU, UK.

${ }^{8}$ Department of Life, Health and Environmental Sciences, University of L'Aquila, 67100 Coppito, L'Aquila, Italy.

${ }^{9}$ Institute for Research, Hospitalization and Health Care (IRCCS) "G. Gaslini" Institute, Genova 16147, Italy.

${ }^{10}$ Division of Neurology, Children's Hospital of Philadelphia; The Epilepsy NeuroGenetics Initiative (ENGIN), Children's Hospital of Philadelphia; Department of Biomedical and Health Informatics (DBHi), Children's Hospital of Philadelphia; Department of Neurology, University of Pennsylvania, Perelman School of Medicine, Philadelphia, Pennsylvania 19104, USA.

${ }^{11}$ Blueprint Genetics, 02150 Espoo, Finland.

${ }^{12}$ Folkhälsan Research Center, Helsinki, Finland; Department of Medical and Clinical Genetics, Medicum, University of Helsinki, Helsinki 00290, Finland. 
medRxiv preprint doi: https://doi.org/10.1101/2021.06.01.21257500; this version posted June 7, 2021. The copyright holder for this preprint (which was not certified by peer review) is the author/funder, who has granted medRxiv a license to display the preprint in perpetuity. It is made available under a CC-BY-NC-ND 4.0 International license .

${ }^{13}$ Epilepsy Research Centre, Department of Medicine, University of Melbourne, Austin Health, Heidelberg, Victoria 3010, Australia.

${ }^{14}$ Neurogenetics Branch, National Institute of Neurological Disorders and Stroke, National Institutes of Health, Maryland 20892, USA.

${ }^{15}$ IRCCS San Raffaele Pisana, 00163 Roma, Italy.

${ }^{16}$ Oxford Harrington Rare Disease Centre, University of Oxford, Oxford OX1 3QX, UK.

${ }^{\dagger}$ These authors contributed equally.

Correspondence to: Carlo Rinaldi

Department of Paediatrics, South Parks Road, OX1 3QX, Oxford, UK

E-mail: carlo.rinaldi@paediatrics.ox.ac.uk

Running title: ATP6VOA1 variants lead to neurodevelopmental disorders.

Keywords: V-ATPase; epileptic encephalopathy; $C$. elegans disease modelling; organelle acidification; lysosomal disease.

\begin{abstract}
The vacuolar $\mathrm{H}^{+}$-ATPase is a large multi-subunit proton pump, composed of an integral membrane V0 domain, involved in proton translocation, and a peripheral V1 domain, catalysing ATP hydrolysis. This complex is widely distributed on the membrane of various subcellular organelles, such as endosomes and lysosomes, and plays a critical role in cellular processes ranging from autophagy to protein trafficking and endocytosis. Variants in ATP6VOA1, the brain-enriched isoform in the $\mathrm{V} 0$ domain, have been recently associated with developmental delay and epilepsy in four individuals. Here we identified 17 individuals from 14 unrelated families with both with new and previously characterised variants in this gene, representing the largest cohort to date. Five affected subjects with biallelic variants in this gene presented with a phenotype of early-onset progressive myoclonus epilepsy with ataxia, while 12 individuals carried de novo missense variants and showed severe developmental and epileptic encephalopathy. The R740Q mutation, which alone accounts for almost $50 \%$ of the mutations identified among our cases, leads to failure of lysosomal hydrolysis by directly impairing acidification of the endolysosomal compartment, causing autophagic dysfunction and severe developmental defect in $C$. elegans. Altogether, our findings further expand the neurological phenotype associated with variants in this gene and provide a direct link with endolysosomal acidification in the pathophysiology of ATP6VOA1-related conditions.
\end{abstract}

\title{
Introduction
}

Vacuolar-type ATPases (V-ATPases) are a ubiquitous, multi-subunit, membrane-embedded rotary proton-pumping motor, arranged into a dissociable peripheral V1 domain (subunits $A$, 
medRxiv preprint doi: https://doi.org/10.1101/2021.06.01.21257500; this version posted June 7, 2021. The copyright holder for this preprint

$B, C, D, E, F, G$ and $H$ ), responsible for ATP hydrolysis, and an integral membrane V0 domain (subunits a, c, c', c", d, e), responsible for proton translocation (Mazhab-Jafari et al., 2016; Roh et al., 2018; Zhao, Benlekbir, \& Rubinstein, 2015). Through vesicular, luminal and extracellular acidification, the V-ATPases play a critical role in a number of both physiological and pathological cellular processes, from membrane trafficking and substrate degradation in lysosome, to viruses and bacterial toxins internalization and cancer growth and invasion (Vasanthakumar \& Rubinstein, 2020). Other non-canonical roles of the VATPase complex, which are not readily attributable to its proton-moving activity, include membrane fusion, nutrient sensing, and scaffold for protein-protein interactions (Hiesinger et al., 2005; Hurtado-Lorenzo et al., 2006; Zhang et al., 2014). Recent studies have highlighted the critical importance of the V-ATPase complex in neuronal homeostasis and dysregulation of $\mathrm{pH}$ has been shown to be a converging pathogenic mechanism for several diseases, including Alzheimer's (Avrahami et al., 2013; Lee et al., 2015), Parkinson's (Betarbet et al., 2000; Boland et al., 2018; Dehay et al., 2010; Pal et al., 2016; Wallings, Connor-Robson, \& Wade-Martins, 2019), amyotrophic lateral sclerosis (Şentürk, Mao, \& Bellen, 2019; Yang \& Klionsky, 2020), and lysosomal storage diseases (LSD) (Folts, Scott-Hewitt, Pröschel, Mayer-Pröschel, \& Noble, 2016; Futerman \& Van Meer, 2004). Mutations in subunits of the $\mathrm{V}$-ATPase have been associated with autosomal recessive osteopetrosis (ATP6VOA3) (Frattini et al., 2000; Kornak et al., 2000) cutis laxa (ATP6VOA2) (Kornak et al., 2008), distal renal tubular acidosis (ATP6V1B1, ATP6VOA4) (Esmail et al., 2018; Karet et al., 1999; Smith et al., 2000), and epileptic encephalopathy (ATP6V1A) (Fassio et al., 2018), suggesting that this is an emerging class of human genetic disorders.

Some of the isoforms have different expression patterns in various tissues, which may allow the regulation of V-ATPase in a cell type and subcellular compartment specific manner. ATP6VOA1 is the brain-enriched isoform of the a subunit in the V0 domain (Morel, 2003) and is part of the CLEAR (Coordinated Lysosomal Expression and Regulation) network of genes regulated by the master transcription factor EB (TFEB) (Palmieri et al., 2011).

Here we report 5 individuals from 2 unrelated families with compound heterozygous variants in ATP6V0A1 presenting with a phenotype of early-onset progressive myoclonus epilepsy (PME) and ataxia and 12 cases with de novo missense variants in the same gene, with severe developmental and epileptic encephalopathy (DEE), resulting from direct impairment of endolysosome acidification and failure of lysosomal functions.

\section{Results}

We have previously identified an Italian family with four members affected by early-onset progressive myoclonus epilepsy (PME) with ataxia and mental retardation, of unknown origin (Coppola et al., 2005). Seeking to unravel the genetic cause of this condition, we performed 
medRxiv preprint doi: https://doi.org/10.1101/2021.06.01.21257500; this version posted June 7, 2021. The copyright holder for this preprint (which was not certified by peer review) is the author/funder, who has granted medRxiv a license to display the preprint in perpetuity. It is made available under a CC-BY-NC-ND 4.0 International license .

whole exome sequencing (WES) in 3 affected and 2 unaffected individuals (Fam. I; Fig. 1A, Supplementary Fig. 1) and found two previously unknown, compound heterozygous variants, c.445delG (p.E149Kfs18) and c.1483C>T (p.R495W) in ATP6V0A1 (NM_001130021.3), that co-segregate with the clinical phenotype (Fig. 1A). From an independent WES screening of 85 PME patients, we identified 1 individual also from Italy with overlapping clinical features, harbouring the same compound heterozygous mutations (Fam. II.1; Fig. 1A, Table 1). Identity by descent analysis showed that the two families are unrelated (PI-HAT value $=0$ ). While the c.445delG is not found in the gnomAD database (Lek et al., 2016), the allelic carrier frequency of the c.1483C>T variant (rs781278654) is 0.00001315 in the control population and predicted to be damaging (PolyPhen score: 0.99). Neither variant was present in an independent cohort of 200 Italian subjects, suggesting low frequency in this population.

We next pooled genetic and clinical de-identified data of patients with severe developmental disorder (DD) enrolled in the Italian Undiagnosed Rare Diseases Network (IURDN) $(n=110)$ (Salvatore et al., 2020) and the Deciphering Developmental Disorders study ( $\mathrm{n}=13,462)$ (Barash et al., 2010) and identified 3 individuals harbouring the de novo variants c.1652G>A (p.G551E) (Fam. IV.1) and c.2219G>A (p.R740Q) (Fam. V/VI.1) heterozygous variants in ATP6VOA1 (Fig. 1A). Lastly we included in the study 9 additional individuals with unresolved DD who underwent diagnostic WES through GeneDx, Peking University First Hospital, and Pitié Salpêtrière University Hospitals, carrying the c.1429T>C (p.S477P) (Fam. III.1), c.2219G >A (p.R740Q) (Fam. VII-XII.1) and c.2411G>A (p.R804H) (Fam. XIII/XIV.1) de novo ATP6VOA1 variants (Fig. 1A). We confirmed the presence of the mutations detected by WES in all individuals by Sanger sequencing and provided segregation data in immediaterelative carriers (Fig. 1B). The mutated residues in ATP6VOA1 are evolutionarily conserved (Fig. 1C).

Altogether, we identified 17 affected subjects with mutations in ATP6VOA1, with p.R740Q being the most recurrent variant (8 subjects) (Fig. 1A, Table 1). The mean age of onset was $11.8 \pm 7.5$ years for individuals carrying the compound heterozygous mutations and $5.8 \pm 4.2$ months for individuals with the de novo mutations (DNMs) (Table 1). Subjects with the de novo variants showed a phenotype of developmental and epileptic encephalopathy (DEE), with frequent seizures, which were refractory to treatment, and severe mental retardation after a period of apparently normal development, with delay or loss of psychomotor milestones (Table 1). Several subjects were found to have microcephaly and other facial and skeletal dysmorphisms (Table 1, Supplementary Fig. 2A and B). Brain biopsy of a stillborn infant carrying the p.R804H variant showed swollen neurons and axons, with accumulation of granular, PAS-positive material, consistent with LSD with neuroaxonal 
medRxiv preprint doi: https://doi.org/10.1101/2021.06.01.21257500; this version posted June 7, 2021. The copyright holder for this preprint (which was not certified by peer review) is the author/funder, who has granted medRxiv a license to display the preprint in perpetuity. It is made available under a CC-BY-NC-ND 4.0 International license .

dystrophy (Fig. 1A, Fig. 2A), while the placenta derived from the mother showed no evidence of storage cells (not shown).

To provide an estimate of the frequency of ATP6VOA1 variants, we analysed the recently published predicted damaging DNMs $(n=45,221)$ from the largest cohort to date of exome sequence data from individuals with severe DD $(n=31,058)$ (Kaplanis et al., 2020). We observed 11 missense mutations in ATP6V0A1, c.2219G>A recurring in 7 patients (6 of which are included in the present study), and concluded that ATP6VOA1 variants are the most common DNMs among all known lysosomal disease (LD) and LSD-associated genes in this database (Supplementary Table 1).

Functional studies in the well characterized Saccharomyces cerevisiae V-ATPase (ScVATPase) (Roh et al., 2018) have shown that the R735 residue in subunit a, corresponding to R740 in human ATP6VOA1, is essential for proton transport into organelles (Kawasaki-Nishi, Nishi, \& Forgac, 2001). Upon protonation of critical glutamates of subunit c, the c-ring rotates, a salt bridge with $\mathrm{R} 735$ is formed, and protons are transferred and pulled into the organelle lumen through a network of polar and negatively charged residues (Mazhab-Jafari et al., 2016). Homology modelling suggests that the identified de novo mutations overall affect organelle acidification by hindering glutamate deprotonation (p.R740Q and p.R804H), deforming the architecture of the protein region devoted to protons exchange (p.G551E), or altering the conformation of the loop that contours the exit of the luminal channel (p.S477P) (Fig. 2B).

To test whether V-ATPase complex function is affected by the mutations in ATP6VOA1, we generated Neuro2a cell lines stably expressing wild type or c.2219G $>A$ (p.R740Q) mutant human ATP6VOA1 and assessed acidification of the endolysosomal compartment using the LysoSensor radiometric probe, which undergoes a $\mathrm{pH}$-dependent emission shift to longer wavelengths in acidic environments. Compared to wild-type, we observed a decrease in redshifted fluorescence signal in mutant ATP6V0A1-expressing cells, indicative of impaired protonation (Fig. 2C). Co-localization of lysosomes with Cathepsin D, an enzyme whose trafficking to the endolysosomal compartment and maturation into an active lysosomal aspartyl protease requires an acidic pH (Braulke \& Bonifacino, 2009; Ghosh, Garde, \& García, 2003; Isidoro, Grässel, Baccino, \& Hasilik, 1991), was nearly completely abolished by the mutant ATP6V0A1 (Fig. 2D and E). Furthermore, western blot analyses showed decreased proteolytic maturation of Preprocathepsin into the active $31 \mathrm{kD}$ form upon autophagy induction with serum starvation or rapamycin treatment in mutant cells compared to wild type (Supplementary Fig. 3A and B). Intriguingly, mutations resulting in the inactivation or mislocalization of Cathepsin D lead to neuronal ceroid lipofuscinosis, suggesting a convergent pathogenic mechanism with other LSDs (Siintola et al., 2006; Steinfeld et al., 2006). Autophagosome turnover, a process dependent on vacuolar 
medRxiv preprint doi: https://doi.org/10.1101/2021.06.01.21257500; this version posted June 7, 2021. The copyright holder for this preprint (which was not certified by peer review) is the author/funder, who has granted medRxiv a license to display the preprint in perpetuity. It is made available under a CC-BY-NC-ND 4.0 International license .

acidification (Yim \& Mizushima, 2020), was also impaired in cells expressing mutant ATP6V0A1, as suggested by the increased ratios of LC3-II to LC3-I and LC3-II levels alone upon autophagy induction, which persisted after removal of rapamycin (Supplementary Fig. 4A and B). We further investigated the impairment of endolysosomal acidification in mutant cells, by assessing Notch signalling, a critical pathway for many cellular processes (Mašek \& Andersson, 2017) and dependent on V-ATPase proton pump activity for its maturation (Baron, 2012; Le Borgne, 2006; Windler \& Bilder, 2010). We observed downregulation of Notch signalling in R740Q cells, with selective reduced expression of Notch target HES-1 and not of the transcriptional coactivator MALM1, and consequent de-repression of cell cycle inhibitor p21 (Fig. 2F and G) (Guiu et al., 2013; Kabos, Kabosova, \& Neuman, 2002).

We turned to the nematode Caenorhabditis elegans to extend our observations in an animal model of LSD (de Voer, Peters, \& Taschner, 2008). Among the genes coding for V-ATPase subunit a in C. elegans, unc-32 is most closely related to human ATP6V0A1 at protein level (Oka, Toyomura, Honjo, Wada, \& Futai, 2001) (56\% sequence identity and 69\% similarity; Fig. 1C). unc-32 is expressed throughout development and adulthood (Lynch, Briggs, \& Hope, 1995; Pujol, Bonnerot, Ewbank, Kohara, \& Thierry-Mieg, 2001) in multiple tissues, with highest levels in neurons (Lynch et al., 1995; Pujol et al., 2001). To evaluate the role of unc-32 in lysosomal function, we engineered a strain to express endogenous LGG-1 (the worm ortholog of Atg8/LC3) fused to mCherry red fluorescent protein using CRISPR/Cas9. Consistent with a role of the V-ATPase complex in the autophagic pathway, RNA interference (RNAi) targeting unc-32 or other V0 subunits (vha-3, vha-4, vha-16, and vha-17) increased LGG-1::mCherry fluorescence levels relative to control (Fig. 3A). Knock-down of unc-32, without altering the levels of other subunits of the V-ATPase complex (Fig. 3B), reduced the expression of components of the autophagic machinery (atg-7, atg-16.2) (Fig. 3C) and lysosomal hydrolytic enzymes (asp-1, cpr-4, cpr-5, imp-2) (Fig. 3D), and increased expression of the stress-responsive autophagy receptor sqst-1 (Fig. 3B). Interestingly, lgg-1 expression was unchanged by unc-32 RNAi, indicating that the observed increase of LGG$1:: m$ Cherry levels (Fig. 3A) is caused by reduced clearance of this protein by the lysosome. We also performed Cas9-mediated editing of unc-32 in a strain that has gfp inserted at the endogenous locus to introduce a point mutation corresponding to $R 740 \mathrm{Q}$ in human ATP6V0A1 (Supplementary Fig. 5A, B and C). Animals homozygous for the mutant unc32(rm20) allele show developmental arrest at early larval stages (Fig. 3E), reduced levels of UNC-32::GFP at the nerve ring (Fig. 3F), as well as a widespread accumulation of enlarged LGG-1::mCherry puncta (Fig. 3G), further demonstrating the essential role of V-ATPase activity in organismal health. 
medRxiv preprint doi: https://doi.org/10.1101/2021.06.01.21257500; this version posted June 7, 2021. The copyright holder for this preprint (which was not certified by peer review) is the author/funder, who has granted medRxiv a license to display the preprint in perpetuity. It is made available under a CC-BY-NC-ND 4.0 International license .

\section{Discussion}

The eukaryotic V-ATPase is a multi-subunit rotary pump, consisting of a soluble catalytic V1 and a membrane-bound V0 components, which mediates the acidification of cellular and intracellular compartments by driving proton translocation across the membrane (Collins \& Forgac, 2020). Over the last years, a number of non-canonical functions of the V-ATPase have been unravelled, which are distinct but functionally related with its primary proton pump role, including membrane fusion, nutrient sensing, and scaffold for protein-protein interactions (Hiesinger et al., 2005; Hurtado-Lorenzo et al., 2006; Zhang et al., 2014). Isoforms of many of the V1 and V0 subunit proteins are encoded by multiple genes or alternatively spliced transcript variants, with tissue specific expression and mechanisms of regulation (Collins \& Forgac, 2020). The ATP6VOA1 gene encodes the a1 isoform, which of the four a-subunits is the most neuronal enriched, mainly localising to the nerve terminals (Morel, Dedieu, \& Philippe, 2003).

Recently, Aoto et al. identified two subjects with intellectual disability and epilepsy carrying a de novo missense $\mathrm{R} 741 \mathrm{Q}$ substitution in ATP6VOA1 and two with biallelic variants, comprising one complete loss of function and the A512P or N534D missense variant (Aoto et al., 2021), respectively corresponding to R740Q, A505P and N527D in the updated accession number NM_001130021.3 used in this manuscript. Here we report 17 subjects from 14 unrelated families carrying the $\mathrm{R} 740 \mathrm{Q}$, other newly identified de novo missense or inherited biallelic variants in this gene, representing the largest cohort of ATP6V0A1associated disease mutations to date. With 58 DNMs (50 missense, 3 indel, 2 splice site, 2 initiator codon, 1 frameshift) in genes of the V-ATPase complex identified in exome sequence data from over 30,000 individuals with severe DD (Kaplanis et al., 2020), and significant association with severe DD for 2 genes of this group (ATP6V0A1 and ATP6V1A) out of 281 , we propose that a V-ATPase-related disease should be considered in individuals presenting with mild-to-profound developmental delays and epilepsy. Using in vitro, computational and $C$. elegans modelling, we next proceeded to study the mechanism of pathogenicity of the $\mathrm{R} 740 \mathrm{Q}$ variant, which is the most prevalent of all the de novo cases reported so far and the one resulting in the most severe phenotype. Our experimental work indicates that the $\mathrm{R} 740 \mathrm{Q}$ variant causes altered organelle acidification and failure of lysosomal hydrolysis directly by impairment of the canonical proton-pumping V-ATPase function. The compromised acidification of the endolysosomal compartments leads to impaired $y$-secretase-mediated processing and release of the Notch intracellular domain (NICD) and reduced expression of Notch target genes. These findings corroborate recent reports indicating that in Drosophila the V-ATPase-mediated acidification of the endolysosomal compartment is required for the activation of Notch in endosomes (Sorensen 
medRxiv preprint doi: https://doi.org/10.1101/2021.06.01.21257500; this version posted June 7, 2021. The copyright holder for this preprint (which was not certified by peer review) is the author/funder, who has granted medRxiv a license to display the preprint in perpetuity. It is made available under a CC-BY-NC-ND 4.0 International license .

\& Conner, 2010) and expression of a dominant negative subunit of V-ATPase in neural precursors reduced Notch signaling and depleted neural stem cells leading to neuronal differentiation (Lange et al., 2011). The severe impairment of the autophagic machinery upon knock down of the ATP6VOA1 ortholog in $C$. elegans, and the reduced protein clearance by lysosomes upon introduction of the $R 740 \mathrm{Q}$ variant in homozygote state reported here, together with the recent description of severe impairment of the lysosomal dysfunction and decreased Cathepsin $D$ activity in homozygous mutant mice harbouring the human R741Q and A512P variants (Aoto et al., 2021), recapitulate the results observed in neuronal cell lines upon overexpression of the $\mathrm{R} 740 \mathrm{Q}$ variant, supporting an antimorphic mode of action of the R740Q and the other de novo variants.

Five individuals from 2 unrelated pedigrees in our cohort carry the biallelic E149Kfs*18 frameshift and R495W substitution and manifest an early onset, progressive myoclonus epilepsy and ataxia, therefore expanding the neurological phenotypes associated with ATP6V0A1 variants beyond the more severe developmental and epileptic encephalopathy observed in the de novo cases. Of note, the parents carrying only one of the variants do not manifest any obvious neurological phenotype, suggesting a mechanism of haploinsufficiency for the inherited variants. The R495W substitution results in loss of a positively charged hydrophobic residue in close proximity of $S 477$ and the luminal channel exit. We speculate that this variant has a less damaging impact on the proton pumping activity, leading to neurological manifestations only when in compound heterozygosity with a null allele. Further work is needed to clarify the precise molecular mechanisms through which the described biallelic and de novo mutations result in a PME and DEE phenotype, respectively. Considering the increasing identification of disease-causing variants in V-ATPase genes and the critical relevance of vacuolar pump-mediated regulation of intracellular $\mathrm{pH}$ in cellular homeostasis in health and disease (Vasanthakumar \& Rubinstein, 2020), this multi-protein complex is rapidly taking centre stage as a molecular hub for unravelling the disease mechanisms of LDs and other human diseases, from cancer to neurodegeneration.

\section{Materials and methods}

\section{Patients}

Ethical approval was obtained from the ethics committee of the following institutes: University of Federico II (Italy), University of L'Aquila (Italy), G. Gaslini Institute (Italy), University of Exeter (UK), Nottingham University Hospital (UK), Salpêtrière Hospital (France), University of Toronto (Canada), University of Ottawa (Canada), St. Luke's Children's Hospital (USA), Floating Hospital for Children at Tufts Medical Center (USA), Gillette Children's Specialty Healthcare Children's Hospital (USA), Children's Hospital of Philadelphia (USA), Peking University First Hospital, Beijing (China). Written consent for the 
medRxiv preprint doi: https://doi.org/10.1101/2021.06.01.21257500; this version posted June 7, 2021. The copyright holder for this preprint (which was not certified by peer review) is the author/funder, who has granted medRxiv a license to display the preprint in perpetuity. It is made available under a CC-BY-NC-ND 4.0 International license .

study was obtained from patients or legal representatives according to the Declaration of Helsinki. When individuals were not contacted directly, de-identified phenotypic and genomic data were used. Patient or guardian consent was given for the publication of the patient's data and clinical information. Patient II.1 was enrolled in a research study aimed at finding the genetic cause of progressive myoclonus epilepsy; Patient III.1, VII.1-X.1, and XIV.1 were referred to GeneDx for clinical whole-exome sequencing for diagnosis of suspected Mendelian disorders as previously described (Retterer et al., 2016); Patient IV.1 was recruited in the Italian Undiagnosed Rare Diseases Network (IURDN; PGR00229, 2016-19); Patient V.1 and VI.1 were part of the Deciphering Developmental Disorders Study (DDD; 10/H0305/83). Patient XI.1 was recruited as part of the Care4Rare Canada research study.

\section{Sequencing and genotyping}

Blood samples were collected and DNA was extracted using standard methods from peripheral blood lymphocytes from the indicated individuals in Figure $1 \mathrm{~A}$.

Fam. I: Exome sequencing was performed as previously described (Rinaldi et al., 2015). Libraries were prepared using the SeqCap EZ Human Exome Library version 2.0 (Roche Nimblegen Inc) and a 100-base pair paired-end run was performed on the HiSeq 2000, with each sample on a single lane of a TruSeq version 2 flow cell (Illumina). Sequence alignment, quality control, and variant calling were performed with BWA, SAMTools, the Genomic Analysis Toolkit, and Picard (http://picard.sourceforge.net/index.shtml). Data analysis was based on the autosomal recessive mode of inheritance. Variant calling and quality score recalibration was performed using GATK (http://www.broadinstitute.org/gatk/). Variants remaining after exome data analysis containing missing data were Sanger sequenced using the BigDye Terminator version 3.1 chemistry (Applied Biosystems), run on an ABI 3730xI analyzer, and analyzed using Sequencher software version 4.2 (Gene Codes Corporation). Fam. II-XIV: Details on sequencing, alignment, variant calling (inherited and de novo) and variant annotation have been described previously (Kaplanis et al., 2020; Kinay et al., 2018; Mazzola et al., 2020; McRae et al., 2017; Muona et al., 2015; Niestroj et al., 2020; Salvatore et al., 2020). Presence or absence of the disease-causing variants was confirmed on DNA of the proband and additional members from each family by Sanger sequencing.

\section{Homology modelling and structure analysis of the human V-ATPase}

Homology models of the subunit a (NM_001130021.3, NP_001123493.1) and C (NM_001694.4, NP_001685.1) belonging to the V0 domain of the human V-ATPase has been built by Robetta server (Kim, Chivian, \& Baker, 2004), using as templates the 3D structures of the homologous subunits in Bos Taurus (Wang et al., 2020) (PDB ID: 6XBW; $97 \%$ and $98 \%$ identity between the homologous subunits a and $\mathrm{c}$ ). The $3 \mathrm{D}$ models of the 
medRxiv preprint doi: https://doi.org/10.1101/2021.06.01.21257500; this version posted June 7, 2021. The copyright holder for this preprint (which was not certified by peer review) is the author/funder, who has granted medRxiv a license to display the preprint in perpetuity. It is made available under a CC-BY-NC-ND 4.0 International license .

G551E and S477P mutants has been built with Robetta (Kim et al., 2004). Structural analysis has been carried out with Coot and Pymol (The PyMOL Molecular Graphics System, Version 1.2r3pre, Schrödinger, LLC).

\section{cDNA cloning and generation of stable cell lines}

Human ATP6VOA1 cDNA was kindly provided by Michael Forgac. Point mutations corresponding to the gene variants identified in the present study were introduced using a QuikChange II site-directed mutagenesis kit (Agilent Technologies) according to the manufacturer's instructions, and subsequently the constructs were cloned into the PiggyBac (PB) Transposon vector clone (Stratech, PB511B-1). For stable transfection, PB Transposon vector and PB Transposase vector (Stratech, PB210PA-1) were transfected at a ratio of 9:1 into Neuro2a cells plated on 24-well plates ( $\sim 50,000$ cells per well). One day after transfection, the cells were trypsinized and transferred as serial dilution to fresh tissue culture plates. Drug selection using $10 \mu \mathrm{g} / \mathrm{mL}$ puromycin started on day 3 and was continued for 2 to 3 weeks until the visible colonies appeared. In order to induce the transgene expression, $1 \mu \mathrm{g} / \mathrm{mL}$ doxycycline was added to the media starting 1 day before transfection.

\section{Immunofluorescence}

After fixation with $4 \%$ paraformaldehyde, slides were placed in blocking solution (10\% normal goat serum and $0.3 \%$ Triton $\mathrm{X}-100$ in phosphate-buffered saline [PBS]) for 45 minutes at room temperature. Primary antibody staining was done at $4^{\circ} \mathrm{C}$ overnight in PBS with $5 \%$ normal goat serum and $0.1 \%$ Triton X-100 (The Dow Chemical Company), using LysoTracker fluorescent dye (L12492, ThermoFischer Scientific) and Cathepsin D antibody (2284, Cell signaling). The slides were then washed 3 times with PBS $(0.1 \%$ Triton X-100 in PBS), incubated with secondary antibody (Invitrogen, 1:500) for 1 hour at room temperature in the dark, and then washed 3 times before drying and adding Vectashield/4',6-diamidino-2phenylinodole stain (Vector Laboratories). Coverslips were mounted with Permount (Fisher Scientific). The cells were imaged and acquired using the PANNORAMIC 250 fluorescent microscope scanner (3DHISTECH). An average of 100 cells from 3 independent experiments per each condition were analysed by a blinded investigator.

\section{Endolysosome pH measurement}

Quantification of lysosomal $\mathrm{pH}$ was determined using Dextran conjugated Lysosensor Yellow/Blue DND-160 (L7545, Invitrogen). Wild-Type and R740 mutant Neruo2a cells were grown in serum starved conditions (DMEM with antibiotics) with $1 \mu \mathrm{g} / \mathrm{mL}$ doxycycline to $\sim 80 \%$ confluence. Cells were then trypsinized, harvested and aliquoted at $100 \mu \mathrm{l}$ into a black 96-well microplate with $5 \mu \mathrm{M}$ Lysosensor probe for $15 \mathrm{~min}$ at $37^{\circ} \mathrm{C}$ with $5 \% \mathrm{CO} 2(50,000$ 
medRxiv preprint doi: https://doi.org/10.1101/2021.06.01.21257500; this version posted June 7, 2021. The copyright holder for this preprint (which was not certified by peer review) is the author/funder, who has granted medRxiv a license to display the preprint in perpetuity. It is made available under a CC-BY-NC-ND 4.0 International license .

cells). The cells were then washed $3 X$ in DMEM and the samples were read in a CLARIOstar Plus spectrophotometer (BMG Labtech) with dual-excitation and dual-emission spectral peaks at $324 / 441$ and $381 / 541 \mathrm{~nm}$. The ratio of emission was then calculated for each sample as indicated.

\section{Western blotting and densitometry analysis}

Whole cell lysates were collected as previously described (Forouhan, Mori, \& BootHandford, 2018). Protein concentration of whole cell lysates were determined using the Pierce bicinchoninic acid protein assay (23227, Thermo Scientific) with a bovine serum albumin standard curve according to the manufacturer's protocol. Twenty micrograms of denatured protein were loaded into the precast $4-12 \%$ Bis-Tris gels (NP0322BOX, Life Technologies) or 16\% Tricine gel (EC6695A, Thermo Scientifc) for LC3 immunoblot. The gel was electroblotted onto $0.45 \mu \mathrm{m}$ nitrocellulose membrane or $0.2 \mu \mathrm{m}$ PVDF membrane for LC3 western blotting, which was then blocked for $1 \mathrm{~h}$ at room temperature with $5 \%$ skim milk in PBS containing $0.1 \%(\mathrm{v} / \mathrm{v})$ Tween-20 and $2 \%(\mathrm{v} / \mathrm{v})$ serum. The membranes were incubated overnight at $4^{\circ} \mathrm{C}$ in $1 / 1000$ dilution of following primary antibodies; Notch isoforms using Notch isoform sampler kit (3640, Cell Signalling), Cathepsin D antibody (2284, Cell signaling), LC3 A/B (12741, Cell Signalling), and GAPDH (sc-47724), and HRP-linked secondary antibodies. Blots were visualized with chemiluminescence reagent (Life Technologies). Densitometric quantification of bands was performed with the ImageJ software and standardized relative to a loading control against a control protein sample on each blot. Ratios were normalized for each individual experiment, with the wild type sample set as 1 .

\section{C. elegans strains and maintenance}

C. elegans were maintained on solid nematode growth medium seeded with E. coli OP50 at $20{ }^{\circ} \mathrm{C}$ using standard methods (Brenner, 1974). Strains used in this study were Bristol N2 and EG9591 [unc-32(ox683[unc-32::gfp +loxP]) III] (Schwartz \& Jorgensen, 2016).

The insertion of mcherry at the 5' end of endogenous $\operatorname{lgg}-1$, and the introduction of a missense mutation corresponding to the substitution of the essential arginine by a glutamine in UNC-32::GFP at position 804 (numbered according to the isoform UNC-32A) into the EG9591 strain, were performed using CRISPR/Cas9 genome editing and resulted in strains AM1219 lgg-1(rm17[lgg-1::mcherry]) II and AM1232 unc-32(rm20[unc-32(R804Q)::gfp +loxP]) III/hT2[bli-4(e937) let-?(q782) qls48] (I;III).

\section{CRISPR/Cas9-mediated genome editing}


medRxiv preprint doi: https://doi.org/10.1101/2021.06.01.21257500; this version posted June 7, 2021. The copyright holder for this preprint (which was not certified by peer review) is the author/funder, who has granted medRxiv a license to display the preprint in perpetuity. It is made available under a CC-BY-NC-ND 4.0 International license .

Genome editing was performed as previously described (Paix, Folkmann, \& Seydoux, 2017). Briefly, Cas9 ribonucleoprotein complexes were assembled in vitro from purified Cas9 (New England Biolabs), tracrRNA and gene specific crRNA (Integrated DNA Technologies), and injected together with a linear DNA repair template in the gonad of adult hermaphrodites. CRISPR editing was performed using $d p y-10$ to generate cn64 rollers as phenotypic marker. Successful edits were identified by PCR screening and verified by Sanger sequencing.

For inserting mcherry at the endogenous lgg-1 locus, we targeted the 5 ' end of the first exon with the guide sequence 5'-CCTTCGAATCAAAATGAAGT-3'. The repair template was synthesized by PCR to generate a double-stranded DNA fragment consisting of mCherry amplified from pAP582 (Addgene) and homology overhangs for insertion at the ATG start site using primers 5'TAACCTTCTCTTCACACTAACCTTCGAATCAAAATGGTCTCAAAGGGTGAAGAAGATAAC $-3$ and 5 CTTCTCAAAGTTGTTCTCCTCCTTGTAAGCCCACTTCTTATACAATTCATCCATGCC-3'.

The $\operatorname{lgg}-1(r m 17)$ allele was isolated in a dpy-10(+) background and the resulting strain was back-crossed three times to N2.

For generating the R804Q substitution in UNC-32::GFP, we edited the unc-32(ox683) allele using the guide sequence 5'-CTGCTTCATACCTTCGTCTT-3' and a single-stranded oligonucleotide containing the CGT>CAG change, a silent $T>G$ mutation resulting in the Pvull restriction site for genotyping, and homology arms flanking the edit as repair template 5'-

TCTTGGATGTGTGTCACATACTGCTTCATACCTTCagCTgTGGGCTCTTTCATTGGCTCA TGCTCGTAAGTAAAG-3'. The resulting unc-32(rm20) allele was confirmed by sequencing and kept on the $h T 2$ balancer for strain maintenance.

\section{RNA interference}

RNAi-mediated knock-down of V-ATPase genes or lgg-1 was performed by feeding animals with $E$. coli strain HT115(DE3) containing the appropriate RNAi vectors obtained from the Ahringer library and using L4440 as the empty vector control (Kamath \& Ahringer, 2003). Bacterial cultures were grown overnight in LB with $100 \mathrm{ug} / \mathrm{mL}$ ampicillin and induced with 5 $\mathrm{mM}$ IPTG for 3 hours at $37^{\circ} \mathrm{C}$ before plating. Animals were age-synchronized by a 2-hour egg-lay on RNAi plates and collected for analysis 72-96 hours later. For RNAi clones that cause developmental defects (vha-4, vha-16, and vha-17), the animals were initially grown on L4440 and transferred to RNAi plates at L4 stage.

\section{Fluorescence imaging}


Animals were immobilized in $50 \mathrm{mM}$ sodium azide on $3 \%$ agarose pads and imaged using a Zeiss LSM800 confocal microscope with 10x or 20x objective and Zen imaging software. For quantification of LGG-1::mCherry fluorescence levels, maximum intensity projections were generated from $Z$ stack images and fluorescence intensity was quantified by tracing either the nerve ring for UNC-32::GFP or whole animals for LGG-1::mCherry using ImageJ software (NIH).

\section{Gene expression analysis in C. elegans}

Age-synchronized populations of at least 100 gravid adults were collected and snap frozen in liquid nitrogen. RNA was extracted using TRIzol (Invitrogen) and purified with QIAGEN RNeasy MinElute columns as per manufacturers' instructions (Sala, Bott, Brielmann, \& Morimoto, 2020). mRNA was reverse transcribed using the iScript cDNA Synthesis Kit (BioRad) and real-time quantitative PCR was performed using iQ SYBR Green Supermix (BioRad) in a BioRad CFX384 Real-Time PCR system. Relative expression was determined from cycle threshold values using the standard curve method and the expression of genes of interest was normalized to $c d c-42$. The primers used are listed in Supplementary Table 2.

\section{Statistical analysis}

Statistical analysis was performed with Graph Pad Prism version 8 for Windows (GraphPad Software, San Diego California USA, www.graphpad.com), using the tests indicated in the figure legends. A standard confidence interval of $95 \%$ was applied in all analyses. Displayed in the figure are the mean values of all technical replicates for each of the independent experiments (displayed as single data points). Error bars represent the standard error of the mean. $P$ values $<0.05$ were considered statistically significant.

\section{Data availability}

The raw data that support the findings of this study are available from the corresponding authors, upon request. 
medRxiv preprint doi: https://doi.org/10.1101/2021.06.01.21257500; this version posted June 7, 2021. The copyright holder for this preprint (which was not certified by peer review) is the author/funder, who has granted medRxiv a license to display the preprint in perpetuity.

It is made available under a CC-BY-NC-ND 4.0 International license .

\section{Acknowledgements}

We are grateful to the participants and the core research staff who made this study possible. We thank Karen L Oliver (University of Melbourne) for the project and case management in the progressive myoclonus epilepsy exome study. We thank Dr. Bryan J. Traynor (National Institute on Aging, NIH) for the help with the exome sequencing of Fam. 1. We thank Michael Forgac for ATP6V0A1 plasmid constructs, the Caenorhabditis Genetics Center and Erik Jorgensen for $C$. elegans strains, Jian $\mathrm{Li}$ and John Rubinstein for valuable discussions, and Renee Brielmann for technical assistance in this project. We also thank the High-Throughput Analysis Lab, the Keck Biophysics Facility, and the laboratory of Robert Lamb at Northwestern University for instrument use.

\section{Funding}

This research was supported in part by the Intramural Research Program of the National Institutes of Health, National Institute of Neurological Disorders and Stroke, grant Z01AG000949-02 from the National Institute on Aging (Dr Johnson). The Italian Network of Rare Diseases is funded by the Italian Ministry of Foreign Affairs and International Cooperation and Farmindustria (PGR00229, 2016-19). The Care4Rare Canada Consortium is funded by Genome Canada and the Ontario Genomics Institute (OGI-147), the Canadian Institutes of Health Research, Ontario Research Fund, Genome Alberta, Genome British Columbia, Genome Quebec, and Children's Hospital of Eastern Ontario Foundation. L.C.B. was supported by postdoctoral fellowships from the National Ataxia Foundation and the American Federation for Aging Research, as well as a research grant from the Kennedy's Disease Association. M.F. and C.R. are supported by the Wellcome Trust under fellowship award 205162/Z/16/Z. W.F.L. is supported by a research grant from the Kennedy's Disease Association and a John Fell Fund from the Medical Science Division of the University of Oxford. R.I.M. received support from the National Institutes of Health (National Institute on Aging R56AG059579, R37AG026647, RF1AG057296, and P01AG054407) and the Daniel F. and Ada L. Rice Foundation. P.S. developed this work within the framework of the DINOGMI Department of Excellence of MIUR 2018-2022 (legge 232 del 2016).

\section{Competing interests}

The authors report no competing interests.

\section{Supplementary material}

Supplementary material is available online. 


\section{Appendix 1}

Appendix contains the list of consortium collaborators.

\section{References}

Aoto, K., Kato, M., Akita, T., Nakashima, M., Mutoh, H., Akasaka, N., ... Saitsu, H. (2021). ATP6V0A1 encoding the a1-subunit of the V0 domain of vacuolar H+-ATPases is essential for brain development in humans and mice. Nature Communications, 12(1). https://doi.org/10.1038/s41467-021-22389-5

Avrahami, L., Farfara, D., Shaham-Kol, M., Vassar, R., Frenkel, D., \& Eldar-Finkelman, H. (2013). Inhibition of glycogen synthase kinase-3 ameliorates $\beta$-amyloid pathology and restores lysosomal acidification and mammalian target of rapamycin activity in the alzheimer disease mouse model: In vivo and in vitro studies. Journal of Biological Chemistry, 288(2), 1295-1306. https://doi.org/10.1074/jbc.M112.409250

Barash, Y., Calarco, J. A., Gao, W., Pan, Q., Wang, X., Shai, O., ... Frey, B. J. (2010). Deciphering the splicing code. Nature, 465(7294), 53-59. https://doi.org/10.1038/nature09000

Baron, M. (2012). Endocytic routes to Notch activation. Seminars in Cell and Developmental Biology, Vol. 23, pp. 437-442. https://doi.org/10.1016/j.semcdb.2012.01.008

Betarbet, R., Sherer, T. B., MacKenzie, G., Garcia-Osuna, M., Panov, A. V., \& Greenamyre, J. T. (2000). Chronic systemic pesticide exposure reproduces features of Parkinson's disease. Nature Neuroscience, 3(12), 1301-1306. https://doi.org/10.1038/81834

Boland, B., Yu, W. H., Corti, O., Mollereau, B., Henriques, A., Bezard, E., ... Millan, M. J. (2018, September 1). Promoting the clearance of neurotoxic proteins in neurodegenerative disorders of ageing. Nature Reviews Drug Discovery, Vol. 17, pp. 660-688. https://doi.org/10.1038/nrd.2018.109

Braulke, T., \& Bonifacino, J. S. (2009, April). Sorting of lysosomal proteins. Biochimica et Biophysica Acta - Molecular Cell Research, Vol. 1793, pp. 605-614. https://doi.org/10.1016/j.bbamcr.2008.10.016

Brenner, S. (1974). The genetics of Caenorhabditis elegans. Genetics, 77(1), 71-94. Retrieved from https://pubmed.ncbi.nlm.nih.gov/4366476/

Collins, M. P., \& Forgac, M. (2020, December 1). Regulation and function of V-ATPases in physiology and disease. Biochimica et Biophysica Acta - Biomembranes, Vol. 1862. https://doi.org/10.1016/j.bbamem.2020.183341

Coppola, G., Criscuolo, C., De Michele, G., Striano, S., Barbieri, F., Striano, P., ... Filla, A. (2005). Autosomal recessive progressive myoclonus epilepsy with ataxia and mental retardation. Journal of Neurology, 252(8), 897-900. https://doi.org/10.1007/s00415- 


\section{5-0766-3}

de Voer, G., Peters, D., \& Taschner, P. E. M. (2008, July). Caenorhabditis elegans as a model for lysosomal storage disorders. Biochimica et Biophysica Acta - Molecular Basis of Disease, Vol. 1782, pp. 433-446. https://doi.org/10.1016/j.bbadis.2008.04.003

Dehay, B., Bové, J., Rodríguez-Muela, N., Perier, C., Recasens, A., Boya, P., \& Vila, M. (2010). Pathogenic lysosomal depletion in Parkinson's disease. Journal of Neuroscience, $30(37), \quad$ 12535-12544. https://doi.org/10.1523/JNEUROSCI.192010.2010

Esmail, S., Kartner, N., Yao, Y., Kim, J. W., Reithmeier, R. A. F., \& Manolson, M. F. (2018). Molecular mechanisms of cutis laxa- and distal renal tubular acidosis-causing mutations in V-ATPase a subunits, ATP6V0A2 and ATP6V0A4. Journal of Biological Chemistry, 293(8), 2787-2800. https://doi.org/10.1074/jbc.M117.818872

Fassio, A., Esposito, A., Kato, M., Saitsu, H., Mei, D., Marini, C., ... Guerrini, R. (2018). De novo mutations of the ATP6V1A gene cause developmental encephalopathy with epilepsy. Brain, 141(6), 1703-1718. https://doi.org/10.1093/brain/awy092

Folts, C. J., Scott-Hewitt, N., Pröschel, C., Mayer-Pröschel, M., \& Noble, M. (2016). Lysosomal Re-acidification Prevents Lysosphingolipid-Induced Lysosomal Impairment

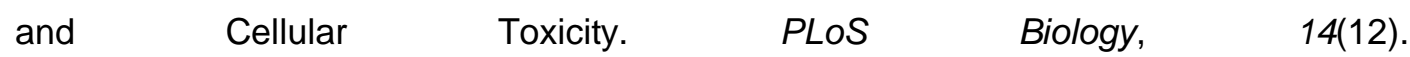
https://doi.org/10.1371/journal.pbio.1002583

Forouhan, M., Mori, K., \& Boot-Handford, R. P. (2018). Paradoxical roles of ATF6a and ATF6 $\beta$ in modulating disease severity caused by mutations in collagen $X$. Matrix Biology, 70, 50-71. https://doi.org/10.1016/j.matbio.2018.03.004

Frattini, A., Orchard, P. J., Sobacchi, C., Giliani, S., Abinun, M., Mattsson, J. P., ... Villa, A. (2000). Defects in TCIRG1 subunit of the vacuolar proton pump are responsible for a subset of human autosomal recessive osteopetrosis. Nature Genetics, 25(3), 343-346. https://doi.org/10.1038/77131

Futerman, A. H., \& Van Meer, G. (2004, July). The cell biology of lysosomal storage disorders. Nature Reviews Molecular Cell Biology, Vol. 5, pp. 554-565. https://doi.org/10.1038/nrm1423

Ghosh, T., Garde, S., \& García, A. E. (2003). Role of Backbone Hydration and Salt-Bridge Formation in Stability of a-Helix in Solution. Biophysical Journal, 85(5), 3187-3193. https://doi.org/10.1016/S0006-3495(03)74736-5

Guiu, J., Shimizu, R., D’Altri, T., Fraser, S. T., Hatakeyama, J., Bresnick, E. H., ... Bigas, A. (2013). Hes repressors are essential regulators of hematopoietic stem cell development downstream of notch signaling. Journal of Experimental Medicine, 210(1), 71-84. https://doi.org/10.1084/jem.20120993

Hiesinger, P. R., Fayyazuddin, A., Mehta, S. Q., Rosenmund, T., Schulze, K. L., Zhai, R. G., 
medRxiv preprint doi: https://doi.org/10.1101/2021.06.01.21257500; this version posted June 7, 2021. The copyright holder for this preprint (which was not certified by peer review) is the author/funder, who has granted medRxiv a license to display the preprint in perpetuity. It is made available under a CC-BY-NC-ND 4.0 International license .

... Bellen, H. J. (2005). The v-ATPase V0 subunit a1 is required for a late step in synaptic vesicle exocytosis in Drosophila. Cell, 121(4), 607-620. https://doi.org/10.1016/j.cell.2005.03.012

Hurtado-Lorenzo, A., Skinner, M., El Annan, J., Futai, M., Sun-Wada, G. H., Bourgoin, S., ... Marshansky, V. (2006). V-ATPase interacts with ARNO and Arf6 in early endosomes and regulates the protein degradative pathway. Nature Cell Biology, 8(2), 124-136. https://doi.org/10.1038/ncb1348

Isidoro, C., Grässel, S., Baccino, F. M., \& Hasilik, A. (1991). Determination of the Phosphorylation, Uncovering of Mannose 6-Phosphate Groups and Targeting of Lysosomal Enzymes. Clinical Chemistry and Laboratory Medicine, 29(3), 165-172. https://doi.org/10.1515/cclm.1991.29.3.165

Kabos, P., Kabosova, A., \& Neuman, T. (2002). Blocking HES1 expression initiates GABAergic differentiation and induces the expression of p21CIP1/WAF1 in human neural stem cells. Journal of Biological Chemistry, 277(11), 8763-8766. https://doi.org/10.1074/jbc.C100758200

Kamath, R. S., \& Ahringer, J. (2003). Genome-wide RNAi screening in Caenorhabditis elegans. Methods, 30(4), 313-321. https://doi.org/10.1016/S1046-2023(03)00050-1

Kaplanis, J., Samocha, K. E., Wiel, L., Zhang, Z., Arvai, K. J., Eberhardt, R. Y., ... Retterer, K. (2020). Evidence for 28 genetic disorders discovered by combining healthcare and research data. Nature, 586(7831), 757-762. https://doi.org/10.1038/s41586-020-2832-5

Karet, F. E., Finberg, K. E., Nelson, R. D., Nayir, A., Mocan, H., Sanjad, S. A., ... Lifton, R. P. (1999). Mutations in the gene encoding B1 subunit of $\mathrm{H}_{+}-A T P a s e$ cause renal tubular acidosis with sensorineural deafness. Nature Genetics, 21(1), 84-90. https://doi.org/10.1038/5022

Kawasaki-Nishi, S., Nishi, T., \& Forgac, M. (2001). Arg-735 of the 100-kDa subunit a of the yeast V-ATPase is essential for proton translocation. Proceedings of the National Academy of Sciences of the United States of America, 98(22), 12397-12402. https://doi.org/10.1073/pnas.221291798

Kim, D. E., Chivian, D., \& Baker, D. (2004). Protein structure prediction and analysis using the Robetta server. Nucleic Acids Research, 32(WEB SERVER ISS.). https://doi.org/10.1093/nar/gkh468

Kinay, D., Oliver, K. L., Tüzün, E., Damiano, J. A., Ulusoy, C., Andermann, E., ... Berkovic, S. F. (2018). Evidence of linkage to chromosome 5p13.2-q11.1 in a large inbred family with genetic generalized epilepsy. Epilepsia, 59(8), e125-e129. https://doi.org/10.1111/epi.14506

Kornak, U., Reynders, E., Dimopoulou, A., Van Reeuwijk, J., Fischer, B., Rajab, A., ... Mundlos, S. (2008). Impaired glycosylation and cutis laxa caused by mutations in the 
medRxiv preprint doi: https://doi.org/10.1101/2021.06.01.21257500; this version posted June 7, 2021. The copyright holder for this preprint (which was not certified by peer review) is the author/funder, who has granted medRxiv a license to display the preprint in perpetuity. It is made available under a CC-BY-NC-ND 4.0 International license .

vesicular H+-ATPase subunit ATP6V0A2. Nature Genetics, 40(1), 32-34. https://doi.org/10.1038/ng.2007.45

Kornak, U., Schulz, A., Friedrich, W., Uhlhaas, S., Kremens, B., Voit, T., ... Kubisch, C. (2000). Mutations in the a3 subunit of the vacuolar H+-ATPase cause infantile malignant osteopetrosis. Human Molecular Genetics, 9(13), 2059-2063. https://doi.org/10.1093/hmg/9.13.2059

Lange, C., Prenninger, S., Knuckles, P., Taylor, V., Levin, M., \& Calegari, F. (2011). The H+ vacuolar ATPase maintains neural stem cells in the developing mouse cortex. Stem Cells and Development, 20(5), 843-850. https://doi.org/10.1089/scd.2010.0484

Le Borgne, R. (2006, April). Regulation of Notch signalling by endocytosis and endosomal sorting. Current Opinion in Cell Biology, Vol. 18, pp. 213-222. https://doi.org/10.1016/j.ceb.2006.02.011

Lee, J. H., McBrayer, M. K., Wolfe, D. M., Haslett, L. J., Kumar, A., Sato, Y., ... Nixon, R. A. (2015). Presenilin 1 Maintains Lysosomal Ca2+ Homeostasis via TRPML1 by Regulating vATPase-Mediated Lysosome Acidification. Cell Reports, 12(9), 1430-1444. https://doi.org/10.1016/j.celrep.2015.07.050

Lek, M., Karczewski, K. J., Minikel, E. V., Samocha, K. E., Banks, E., Fennell, T., ... Williams, A. L. (2016). Analysis of protein-coding genetic variation in 60,706 humans. Nature, 536(7616), 285-291. https://doi.org/10.1038/nature19057

Lynch, A. S., Briggs, D., \& Hope, I. A. (1995). Developmental expression pattern screen for genes predicted in the C. elegans genome sequencing project. Nature Genetics, 11(3), 309-313. https://doi.org/10.1038/ng1195-309

Mašek, J., \& Andersson, E. R. (2017, May 15). The developmental biology of genetic notch disorders. Development (Cambridge), Vol. 144, pp. 1743-1763. https://doi.org/10.1242/dev.148007

Mazhab-Jafari, M. T., Rohou, A., Schmidt, C., Bueler, S. A., Benlekbir, S., Robinson, C. V., \& Rubinstein, J. L. (2016). Atomic model for the membrane-embedded VO motor of a eukaryotic V-ATPase. Nature, 539(7627), 118-122. https://doi.org/10.1038/nature19828

Mazzola, L., Oliver, K. L., Labalme, A., Baykan, B., Muona, M., Joensuu, T. H., ... Lesca, G. (2020). Progressive Myoclonus Epilepsy Caused by a Homozygous Splicing Variant of SLC7A6OS . Annals of Neurology. https://doi.org/10.1002/ana.25941

McRae, J. F., Clayton, S., Fitzgerald, T. W., Kaplanis, J., Prigmore, E., Rajan, D., ... Hurles, M. E. (2017). Prevalence and architecture of de novo mutations in developmental disorders. Nature, 542(7642), 433-438. https://doi.org/10.1038/nature21062

Morel, N. (2003). Neurotransmitter disease: The dark side of the vacuolar-H+ATPase. Biology of the Cell, Vol. 95, pp. 453-457. https://doi.org/10.1016/S0248- 
4900(03)00075-3

Morel, N., Dedieu, J. C., \& Philippe, J. M. (2003). Specific sorting of the a1 isoform of the V$\mathrm{H}+\mathrm{ATPase}$ a subunit to nerve terminals where it associates with both synaptic vesicles and the presynaptic plasma membrane. Journal of Cell Science, 116(23), 4751-4762. https://doi.org/10.1242/jcs.00791

Muona, M., Berkovic, S. F., Dibbens, L. M., Oliver, K. L., Maljevic, S., Bayly, M. A., ... Lehesjoki, A. E. (2015). A recurrent de novo mutation in KCNC1 causes progressive myoclonus epilepsy. Nature Genetics, 47(1). https://doi.org/10.1038/ng.3144

Niestroj, L. M., Perez-Palma, E., Howrigan, D. P., Zhou, Y., Cheng, F., Saarentaus, E., ... Lal, D. (2020). Epilepsy subtype-specific copy number burden observed in a genomewide study of 17458 subjects. Brain, 143(7), 2106-2118. https://doi.org/10.1093/brain/awaa171

Oka, T., Toyomura, T., Honjo, K., Wada, Y., \& Futai, M. (2001). Four subunit a isoforms of Caenorhabditis elegans vacuolar $\mathrm{H}$ +-ATPase: Cell-specific expression during development. Journal of Biological Chemistry, 276(35), 33079-33085. https://doi.org/10.1074/jbc.M101652200

Paix, A., Folkmann, A., \& Seydoux, G. (2017). Precision genome editing using CRISPRCas9 and linear repair templates in C. elegans. Methods, 121-122, 86-93. https://doi.org/10.1016/j.ymeth.2017.03.023

Pal, R., Bajaj, L., Sharma, J., Palmieri, M., Di Ronza, A., Lotfi, P., ... Rodney, G. G. (2016). NADPH oxidase promotes Parkinsonian phenotypes by impairing autophagic flux in an mTORC1-independent fashion in a cellular model of Parkinson's disease. Scientific Reports, 6. https://doi.org/10.1038/srep22866

Palmieri, M., Impey, S., Kang, H., di Ronza, A., Pelz, C., Sardiello, M., \& Ballabio, A. (2011). Characterization of the CLEAR network reveals an integrated control of cellular clearance pathways. Human Molecular Genetics, 20(19), 3852-3866. https://doi.org/10.1093/hmg/ddr306

Pujol, N., Bonnerot, C., Ewbank, J. J., Kohara, Y., \& Thierry-Mieg, D. (2001). The Caenorhabditis elegans unc-32 Gene Encodes Alternative Forms of a Vacuolar ATPase a Subunit. Journal of Biological Chemistry, 276(15), 11913-11921. https://doi.org/10.1074/jbc.M009451200

Retterer, K., Juusola, J., Cho, M. T., Vitazka, P., Millan, F., Gibellini, F., ... Bale, S. (2016). Clinical application of whole-exome sequencing across clinical indications. Genetics in Medicine, 18(7), 696-704. https://doi.org/10.1038/gim.2015.148

Rinaldi, C., Schmidt, T., Situ, A. J., Johnson, J. O., Lee, P. R., Chen, K. L., ... Fischbeck, K. $\mathrm{H}$. (2015). Mutation in CPT1C associated with pure autosomal dominant spastic paraplegia.

Neurology,

$72(5)$,

561-570. 
https://doi.org/10.1001/jamaneurol.2014.4769

Roh, S. H., Stam, N. J., Hryc, C. F., Couoh-Cardel, S., Pintilie, G., Chiu, W., \& Wilkens, S. (2018). The 3.5- $\AA$ CryoEM Structure of Nanodisc-Reconstituted Yeast Vacuolar ATPase Vo Proton Channel. Molecular Cell, 69(6), 993-1004.e3. https://doi.org/10.1016/j.molcel.2018.02.006

Sala, A. J., Bott, L. C., Brielmann, R. M., \& Morimoto, R. I. (2020). Embryo integrity regulates maternal proteostasis and stress resilience. Genes and Development, 34(9-10), 678687. https://doi.org/10.1101/gad.335422.119

Salvatore, M., Polizzi, A., De Stefano, M. C., Floridia, G., Baldovino, S., Roccatello, D., ... Taruscio, D. (2020). Improving diagnosis for rare diseases: The experience of the Italian undiagnosed Rare diseases network. Italian Journal of Pediatrics, 46(1). https://doi.org/10.1186/s13052-020-00883-8

Schwartz, M. L., \& Jorgensen, E. M. (2016). SapTrap, a toolkit for high-throughput CRISPR/Cas9 gene modification in Caenorhabditis elegans. Genetics, 202(4), 12771288. https://doi.org/10.1534/genetics.115.184275

Şentürk, M., Mao, D., \& Bellen, H. J. (2019, August 3). Loss of proteins associated with amyotrophic lateral sclerosis affects lysosomal acidification via different routes. Autophagy, Vol. 15, pp. 1467-1469. https://doi.org/10.1080/15548627.2019.1609863

Siintola, E., Partanen, S., Strömme, P., Haapanen, A., Haltia, M., Maehlen, J., ... Tyynelä, J. (2006). Cathepsin D deficiency underlies congenital human neuronal ceroidlipofuscinosis. Brain, 129(6), 1438-1445. https://doi.org/10.1093/brain/awl107

Smith, A. N., Skaug, J., Choate, K. A., Nayir, A., Bakkaloglu, A., Ozen, S., ... Karet, F. E. (2000). Mutations in ATP6N1B, encoding a new kidney vacuolar proton pump 116-kD subunit, cause recessive distal renal tubular acidosis with preserved hearing. Nature Genetics, 26(1), 71-75. https://doi.org/10.1038/79208

Sorensen, E. B., \& Conner, S. D. (2010). Y-secretase-dependent cleavage initiates notch signaling from the plasma membrane. Traffic, 11(9), 1234-1245. https://doi.org/10.1111/j.1600-0854.2010.01090.x

Steinfeld, R., Reinhardt, K., Schreiber, K., Hillebrand, M., Kraetzner, R., Brück, W., ... Gärtner, J. (2006). Cathepsin D deficiency is associated with a human neurodegenerative disorder. American Journal of Human Genetics, 78(6), 988-998. https://doi.org/10.1086/504159

Vasanthakumar, T., \& Rubinstein, J. L. (2020, April 1). Structure and Roles of V-type ATPases. Trends in Biochemical Sciences, Vol. 45, pp. 295-307. https://doi.org/10.1016/j.tibs.2019.12.007

Wallings, R., Connor-Robson, N., \& Wade-Martins, R. (2019). LRRK2 interacts with the vacuolar-type $\mathrm{H}_{+}-\mathrm{ATP}$ ase pump a1 subunit to regulate lysosomal function. Human 
medRxiv preprint doi: https://doi.org/10.1101/2021.06.01.21257500; this version posted June 7, 2021. The copyright holder for this preprint (which was not certified by peer review) is the author/funder, who has granted medRxiv a license to display the preprint in perpetuity. It is made available under a CC-BY-NC-ND 4.0 International license .

Molecular Genetics, 28(16), 2696-2710. https://doi.org/10.1093/hmg/ddz088

Wang, R., Long, T., Hassan, A., Wang, J., Sun, Y., Xie, X. S., \& Li, X. (2020). Cryo-EM structures of intact V-ATPase from bovine brain. Nature Communications, 11(1). https://doi.org/10.1038/s41467-020-17762-9

Windler, S. L., \& Bilder, D. (2010). Endocytic Internalization Routes Required for Delta/Notch Signaling. Current Biology, 20(6), 538-543. https://doi.org/10.1016/j.cub.2010.01.049

Yang, Y., \& Klionsky, D. J. (2020, January 2). A novel role of UBQLNs (ubiquilins) in regulating autophagy, MTOR signaling and v-ATPase function. Autophagy, Vol. 16, pp. 1-2. https://doi.org/10.1080/15548627.2019.1665293

Yim, W. W. Y., \& Mizushima, N. (2020, December 1). Lysosome biology in autophagy. Cell Discovery, Vol. 6. https://doi.org/10.1038/s41421-020-0141-7

Zhang, C. S., Jiang, B., Li, M., Zhu, M., Peng, Y., Zhang, Y. L., ... Lin, S. C. (2014). The lysosomal v-ATPase-ragulator complex is a common activator for AMPK and mTORC1, acting as a switch between catabolism and anabolism. Cell Metabolism, 20(3), 526540. https://doi.org/10.1016/j.cmet.2014.06.014

Zhao, J., Benlekbir, S., \& Rubinstein, J. L. (2015). Electron cryomicroscopy observation of rotational states in a eukaryotic V-ATPase. Nature, 521(7551), 241-245. https://doi.org/10.1038/nature14365

\section{Figure legends}

Figure 1: Identification of disease mutations in ATP6V0A1. (A) Pedigrees of all families included in the study are shown. Filled symbols represent affected individuals and are numbered within the family. Asterisks indicate subjects who underwent whole-exome sequencing (red) or confirmatory Sanger sequencing (black). Abbreviations: Fam. = family. (B) Representative electropherograms of genomic DNA sequencing of unaffected (top panel) and affected (bottom panel) individuals with identified mutations indicated by arrows. Gene symbol, reference sequence and genomic position of the changes are displayed above the electropherograms. (C) Sequence alignment of ATP6V0A1 protein across multiple species shows evolutionary conservation of the identified mutated residues, indicated by the black arrowhead, and surrounding regions. Gaps (black lines) are inserted between residues so that identical or similar amino acids are aligned in successive columns. Acidic residues (Asp, Glu) are in blue, basic residues (Arg, His, Lys) are in magenta, uncharged polar amino acids (Ser, Thr, Tyr, Asn, GIn) and Gly and Cys are in green, and nonpolar amino acids aside from Gly and Cys (Ala, Val, Phe, Pro, Met, lle, Leu, Trp) are in red. 
medRxiv preprint doi: https://doi.org/10.1101/2021.06.01.21257500; this version posted June 7, 2021. The copyright holder for this preprint (which was not certified by peer review) is the author/funder, who has granted medRxiv a license to display the preprint in perpetuity. It is made available under a CC-BY-NC-ND 4.0 International license .

Figure 2: De novo ATP6VOA1 mutations impair endolysosome acidification and activity. (A) Brain histopathology of subject P:XIV.1 shows swollen neurons (arrows) and axons (arrowheads) with granular periodic acid-Schiff (PAS)-positive deposits (top left panel: haematoxylin and eosin staining; top right panel: PAS staining; bottom left panel: neurofilament light chain staining, bottom right panel: beta-amyloid precursor protein staining). (B) Representation of the homology model of the human V-ATPase pump and localization of the de novo mutations. On the left, the cytosolic V1 region (in grey ribbons) and the V0 membrane-embedded domain (the subunit a and the c-ring are in cyan and pink ribbons) are reported together with their relative functions of ATP hydrolysis and proton transport, respectively. In the centre of the figure, the G551, R740 and R804 mutations in the ATP6VOA1 gene are represented in sticks and their position on transmembrane helix (TM) 4, 7 and 8 and with respect to the protonated residue E139 of the subunit c (V-type proton ATPase $16 \mathrm{kDa}$ proteolipid subunit, NP_001685.1) is magnified on the right. S477 is localized at the exit of the luminal channel as indicated at the bottom of the figure. (C) Fluorescence intensity ratio of yellow $(541 \mathrm{~nm}) / \mathrm{blue}(441 \mathrm{~nm})$ wavelengths of LysoSensor measured in Neuro2a cells expressing wild-type or R740Q mutant ATP6V0A1 mutant cells. (D) Neuro2a cells were treated with rapamycin (Rap $100 \mathrm{nM} ; 12 \mathrm{~h}$ ) or chloroquine (CQ 50 $\mu \mathrm{M} ; 12 \mathrm{~h}$ ), preincubated with LysoTracker (red) and stained with Cathepsin D antibody (green) and DAPI (blue). Single channel (left), merged (centre), and inset (right) images are shown. Scale bars, $100 \mu \mathrm{m}$ (merged) and $50 \mu \mathrm{m}$ (inset). (E) Quantitative analysis of LysoTracker and Cathepsin D-positive compartments is shown. (F) Immunoblotting of R740Q Neuro2a mutant cells showed downregulation of the Notch signalling pathway, which relies on endosome and lysosome acidification, with activation of the cyclin-dependent kinase inhibitor p21. GAPDH is used as loading control. Abbreviations: Notch Transmembrane (NTM), Notch intracellular domain (NICD), Mastermind-like 1 (MAML1), Hairy and Enhancer of Split 1 (HES1). Displayed membranes are cropped and three independent experiments are shown. (G) Densitometry of the intensity of the immunoblot signals were normalised to GAPDH and expressed as fold change of R740Q mutant ATP6V0A1 samples relative to wild type. Individual data points represent independent measurements and are displayed as mean \pm s.e.m. $\mathrm{P}$ values derived from unpaired twotailed t-test are shown.

Figure 3: Loss of the V-ATPase a1 subunit unc-32 causes widespread autophagy defects in C. elegans. (A) Confocal micrographs of age-synchronized adult animals expressing mCherry-tagged LGG-1 after treatment with RNAi targeting lgg-1, indicated VATPase genes or empty vector control. Scale bar, $200 \mu \mathrm{m}$. (B-D) Expression analysis of indicated genes relative to $c d c-42$ in wild-type animals grown on unc-32 RNAi normalized to 
vector control. (B) Expression level of V-ATPase subunit genes belonging to the V0 (unc-32, vha-4, vha-16, vha-17) and the V1 domain (vha-12, vha-15, vha-18) after unc-32 RNAi treatment. (C) Expression level of genes belonging to the autophagic machinery after unc-32 RNAi treatment. (D) Expression level of lysosomal enzymes in animals treated with unc-32 RNAi. Individual data points represent independent measurements and are displayed as mean \pm s.e.m. $P$ values derived from unpaired two-tailed t-test are indicated with one or more asterisks $\left({ }^{*} \mathrm{P}<0.05,{ }^{* *} \mathrm{P}<0.01,{ }^{* * *} \mathrm{P}<0.001\right)$. (E) Representative confocal micrographs of unc-32(ox683) and unc-32(rm20) larvae expressing GFP-tagged wild-type or mutant UNC-32, respectively, as well as LGG-1::mCherry. Animals were imaged 24 hours post egglay, and the head and centre region are shown as magnified selection (dotted lines). Scale bar, $50 \mu \mathrm{m}$. (F) Quantification of UNC-32::GFP fluorescence intensity levels at the nerve ring in unc-32(ox683) and unc-32(rm20) animals. (G) Quantification of LGG-1::mCherry fluorescence intensity levels in unc-32(ox683) and unc-32(rm20) animals. Individual data points represent 9 animals from 2 independent experiments and are displayed as mean \pm s.e.m. $P$ value derived from unpaired two-tailed t-test is reported with asterisks ( ${ }^{* * *}$ $\mathrm{P}<0.001)$. 


\section{Figure 1}

a Fam. I

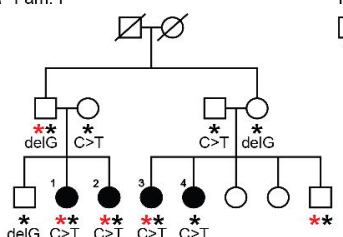

delG delG delG delG

b ATP6VOA1

NM_001130021.3

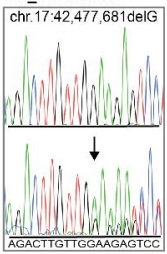

Homo sapiens

Pan troglodytes

Cani lupus

Bos Taurus

Mus musculus

Rattus norvegicus

Gallus gallus

D. melanogaster

C. elegans

S. cerevisiae
Fam. I/ II

\section{p.E149Kfs*18}

$\nabla$

MADPDLLEESSSLLEPSE MADPDLLEESSSLLEPSE MADPDLLEESSSLLEPSE MADPDILEESSSILEPSE MADPDLLEESSSLLEPNE MADPDLLEESSSLLEPNE MADPDLLEES SLLEPSE MADNONEDEQAQILIGEEG RRETRPLIDIGDMDDDSA ED----MIDA----NGEN
Fam. II $\quad$ Fam. III
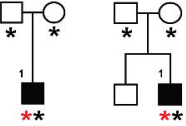

* Exome sequencing

* Sanger sequencing

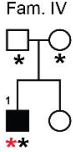

Fam. V Fam. VI

Fam. VII
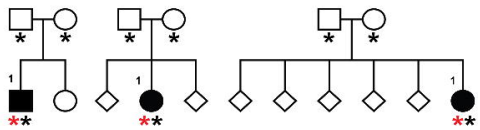

Fam. IX

Fam. VIII

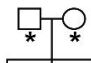

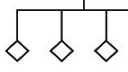

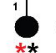

$>$

Fam. X

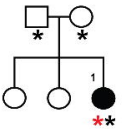

Fam. XI

$\square_{*}$

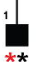

Fam. XII

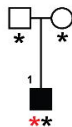

*

Fam. XIV

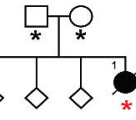

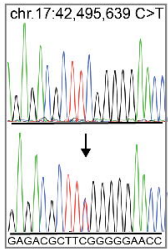
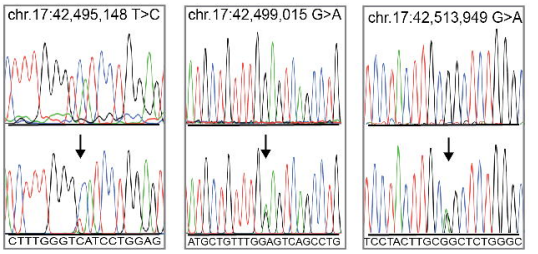
p.R495W

7

T-YNWTBETLRGNPVLO T-YNWTEETLRGNPVLQ TIYNWTEETLRGNPVLQ DIYNWTEETLRGNPVLQ TQGNWTEETLLGSSVLQ TIGNWTEETLLGSSVLQ SKANWSDELLKTTPLIQ --LSYNKSTVMENKFLQ SVIDYYLDDEKRSESQL ---DHWKKGESITAT--
Fam. III

Fam. IV

p.G551E

\section{7}

IYNDCESKSLNIFGSSWS IYNDCFSKSLNIFGSSWS IYNDCESKSLNIFGSSWS IYNDCFSKSLNIFGSSWS IYNDCESKSLNIFGSSWS IYNDCESKSLNIFGSSWS IYNDCESKSLNMEGSSWS IYNDIFSKSLNIFGSHWH MYNDVFSKSINTFGSSWO LYNDIFSKTMTIFKSGWK
ILGI IHMLFGVSLSLFWHI ILGIIHMLFGVSLSLFNHI ILGI IHMMEGVILSIFNHI ILGI IHML FGVSLSLENHT ILGI IHMLFGVSLSLFNHI ILGI IHMLFGVSLSLFNHI ILGI IHMLFGVMLSLLNHI IFGV IHMIFGVWMSWHNHT IMGH'I HMTYSYF'FSLANHL LFGIAOMI FGVLLSYONF I

\begin{tabular}{|c|c|}
\hline Fam. V-XII & Fam. XIII/ XIV \\
\hline p.R740Q & p.R804H \\
\hline CLGCISNTASYLRLWALSLAH- & EGLSAFLHALRLHWVEFQ \\
\hline CLGCISNIASYLRLWALSLAHA & EGLSAFLHALRLHWVEFO \\
\hline CLGCISNTASYLRLWALSLAHA & EGLSAFLHALRLHWVEFO \\
\hline CLGCISNTASYIRLWALSLAHA & EGLSAFTHATRLHWVEFO \\
\hline CLGCISNTASYLRLWALSLAHA & EGLSAFLHALRLHWVEFQ \\
\hline CLGCISNTASYLRLWALSLAHA & EGLSAFLHALRLHWVEFO \\
\hline CLGCISNTASYLRLWALSLAHA & EGLSAF'LHALRLHWIEFQ \\
\hline VLGSVSHTASYTIRLNALSILAHZ & EGLSAFLHTLRT,HWVEFQ \\
\hline VLGCVSHTASYLRLWALSLAHA & EGLSAFLHALRLHWVEFQ \\
\hline CLNCVSHTASYLRLWALSLAHA & EGTSAMLHSLRLHWVESM \\
\hline
\end{tabular}

Blue $=\mathrm{DE}$ (acidic)

Magenta $=$ RHK (basic)

Green = STYCNGQ (hydroxyl + amine + basic)

Red = AVFPMILW (small + hydrophobic) 
Figure 3

A
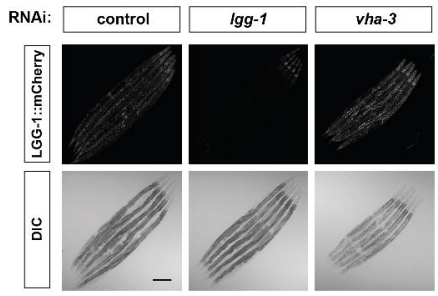

C

control

unc-32 RNAi
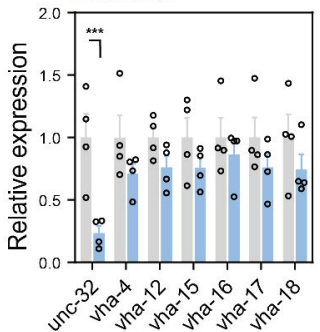

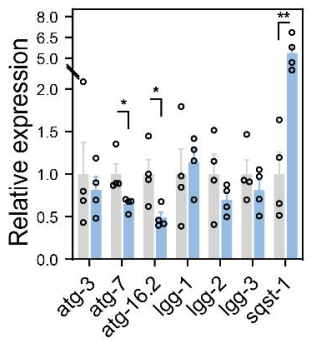

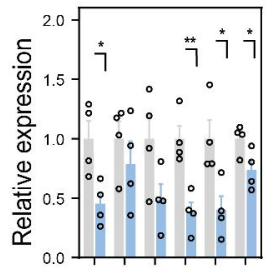

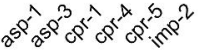

F
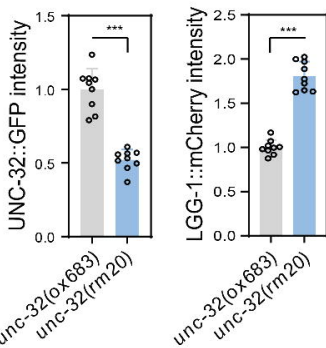

\section{G}

\section{LGG-1::mCherry}

UNC-32::GFP

Merged

Brightfield

Magnified selection

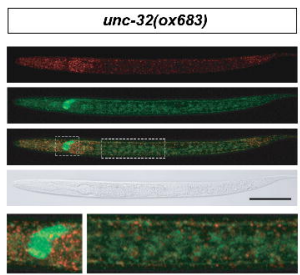

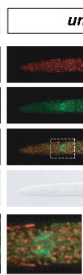

unc-32(rm20)
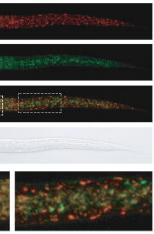

D

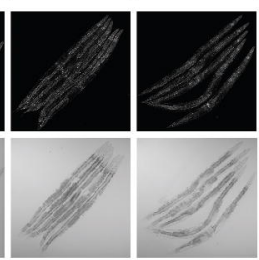




\begin{tabular}{|c|c|c|c|c|c|c|c|c|c|c|c|c|c|c|}
\hline \multicolumn{15}{|c|}{ stics } \\
\hline & P:I.1-4 & P:Il.1 & P:III.1 & $\begin{array}{l}\text { P:IV.1 } \\
\end{array}$ & $\mathrm{P}: \mathrm{V} .1$ & $\begin{array}{l}\mathrm{P}: \mathrm{V} .1 \\
\end{array}$ & P:VII.1 & P:VIIII.1 & P:IX.1 & $P: X .1$ & P:Xl.1 & P:XII.1 & P:XIII.1 & $\mathrm{P}: \mathrm{XIV.1}$ \\
\hline Protein change & \begin{tabular}{|c|} 
p.E149Kfs* $18 ;$ \\
p.495W
\end{tabular} & $\begin{array}{l}\text { p.E149Kfs*18; } \\
\text { p.495W }\end{array}$ & p.S477P & p.G551E & p.R740Q & p.R740Q & p.R740Q & p.R740Q & p.R740Q & p.R740Q & p.R740Q & p.R740Q & p.R804H & p.R804H \\
\hline Zygosity & Biallelic & Biallelic & $\begin{array}{l}\text { Heterozygous } \\
\text { (de novo) }\end{array}$ & $\begin{array}{l}\text { Heterozygous } \\
\text { (de novo) }\end{array}$ & $\begin{array}{l}\text { Heterozygous } \\
\text { (de novo) }\end{array}$ & $\begin{array}{l}\text { Heterozygous } \\
\text { (de novo) }\end{array}$ & $\begin{array}{l}\text { Heterozygous } \\
\text { (de novo) }\end{array}$ & $\begin{array}{l}\text { Heterozygous } \\
\text { (de novo) }\end{array}$ & $\begin{array}{l}\text { Heterozygous } \\
\text { (de novo) }\end{array}$ & $\begin{array}{l}\text { Heterozygous } \\
\text { (de novo) }\end{array}$ & $\begin{array}{l}\text { Heterozygous } \\
\text { (de novo) }\end{array}$ & $\begin{array}{l}\text { Heterozygous } \\
\text { (de novo) }\end{array}$ & $\begin{array}{l}\text { Heterozygous } \\
\text { (de novo) }\end{array}$ & $\begin{array}{l}\text { Heterozygous } \\
\text { (de novo) }\end{array}$ \\
\hline Sex & $F(4)$ & M & M & M & M & $\mathrm{F}$ & $\mathrm{F}$ & $\mathrm{F}$ & $\mathrm{F}$ & $\mathrm{F}$ & M & M & M & $\mathrm{F}$ \\
\hline Age of onset & $\begin{array}{c}8 \text { years (range } \\
4-12)\end{array}$ & 24 years & 4 months & 7 months & 11 months & 12 months & 5 months & 2 months & 2 months & 6 months & 3 months & 3 days & 12 months & Stillborn \\
\hline Initial symptom & Seizures & Seizures & Hypotonia & $\begin{array}{l}\text { Development } \\
\text { delay }\end{array}$ & $\begin{array}{l}\text { Infantile } \\
\text { spasms; Lip } \\
\text { smacking }\end{array}$ & Seizures & $N / A$ & $\begin{array}{c}\text { Abnormal hand } \\
\text { movements }\end{array}$ & $\begin{array}{l}\text { Infantile } \\
\text { spasms }\end{array}$ & $\begin{array}{l}\text { Development } \\
\text { delay }\end{array}$ & Seizures & Seizures & Speech delay & $\mathrm{N} / \mathrm{A}$ \\
\hline $\begin{array}{l}\text { Epilepsy/ EEG } \\
\text { abnormalities }\end{array}$ & Yes & Yes & No & Yes & Yes & Yes & Yes & Yes & Yes & Yes & Yes & Yes & No & $\mathrm{N} / \mathrm{A}$ \\
\hline Intellectual disability & Yes & Yes & N/A & Yes & Yes & Yes & N/A & Yes & Yes & Yes & Yes & Yes & Yes & $\mathrm{N} / \mathrm{A}$ \\
\hline $\begin{array}{l}\text { Slowing of } \\
\text { developmental progress }\end{array}$ & No & No & Yes & Yes & Yes & Yes & Yes & Yes & Yes & Yes & Yes & Yes & Yes & $\mathrm{N} / \mathrm{A}$ \\
\hline Ataxia & Yes & Yes & No & No & No & Yes & Yes & Yes & Yes & Yes & Yes & No & No & N/A \\
\hline Myoclonus & Yes & Yes & No & $\mathrm{N} / \mathrm{A}$ & No & Yes & No & No & No & Yes & No & No & No & $\mathrm{N} / \mathrm{A}$ \\
\hline Brain MRI & $\begin{array}{c}\text { Cerebral and } \\
\text { cerebellar } \\
\text { atrophy }\end{array}$ & $\begin{array}{l}\text { Cerebral and } \\
\text { cerebellar } \\
\text { atrophy }\end{array}$ & Normal & $\begin{array}{l}\text { White-matter } \\
\text { gliosis }\end{array}$ & $\begin{array}{l}\text { Microcephaly, } \\
\text { skull and brain } \\
\text { asymmetry }\end{array}$ & N/A & Normal & Microcephaly & Microcephaly & $\begin{array}{c}\text { Asymmetric } \\
\text { volume loss } \\
\text { throughout the } \\
\text { left hemisnhere }\end{array}$ & Microcephaly & $\begin{array}{l}\text { Cerebral and } \\
\text { cerebellar } \\
\text { atrophy }\end{array}$ & $\begin{array}{l}\text { Microcephaly, } \\
\text { simplified } \\
\text { gyration }\end{array}$ & $\mathrm{N} / \mathrm{A}$ \\
\hline Dysmorphic features & Prognathism & N/A & No & No & Plagiocephaly & Prognathism & No & N/A & $\begin{array}{c}\text { Micrognathia, } \\
\text { bitemporal } \\
\text { narrowing }\end{array}$ & No & N/A & No & Prognathism & $\begin{array}{l}\text { Micrognathia, } \\
\text { hypertelorism }\end{array}$ \\
\hline Additional features & $\mathrm{N} / \mathrm{A}$ & $\mathrm{N} / \mathrm{A}$ & $\begin{array}{c}\text { Scoliosis, } \\
\text { pectus } \\
\text { carinatum, } \\
\text { laryngomalacia }\end{array}$ & $\begin{array}{l}\text { Amelogenesis } \\
\text { imperfecta, } \\
\text { clubfoot }\end{array}$ & Scoliosis & N/A & $\mathrm{N} / \mathrm{A}$ & $\begin{array}{c}\text { Severe } \\
\text { dystonia }\end{array}$ & Optic atrophy & N/A & N/A & $\mathrm{N} / \mathrm{A}$ & N/A & N/A \\
\hline
\end{tabular}

